\title{
Pasang Surut Kerajinan Patung Kayu Pada Industri Pariwisata Di Desa Batubulan Kangin
}

\author{
I Wayan Arissusila ${ }^{1}$, Ni Luh Putu Trisdiyani ${ }^{2}$ \\ ${ }^{12}$ Universitas Hindu Indonesia Denpasar \\ ${ }^{1}$ wayanarisusila2017@gmail.com, ํokybali@yahoo.com
}

\begin{tabular}{l}
\hline Keywords: \\
\hline Tidal, Wooden \\
Sculpture Craft \\
and Tourism \\
Industry \\
\hline
\end{tabular}


Kata Kunci:

Pasang Surut, Kerajinan Patung

Kayu dan Industri

Pariwisata

\begin{abstract}
Abstrak
Kerajinan patung kayu di Desa Batubulan Kangin diawali tahun 1968. Proses belajar kurang lebih dari dua puluh orang, dan mengambil tempat di Desa Guang. Tahun 1970 setelah mereka mahir membuat patung, barulah mengajar ke desanya mulai patung Garuda, Ramayana dan lain-lain. Kerajinan tersebut, memiliki peluang pemasaran dan memotivasi perajin untuk meningkatkan kreatifitasnya. Ketika terjadi bom Bali I, dan pasar globalisasi, kerajinan tersebut mengalami penurunan. Berdasarkan hal itu adapun permasalahan diajukan yaitu: Bagaimana proses perwujudan kerajinan patung kayu, produk apa saja yang dihasilkan, dan bagaiman pasang surut kerajinan patung kayu di Desa Batubulan Kangin. Tujuan penelitian ini untuk mendeskripsikan pasang surut kerajinan patung kayu pada industri pariwisata di Desa Batubulan Kangin. Penelitian ini menggunakan teknik pengumpulan data dilakukan dengan observasi, wawancara dan studi dokumen. Analisis data dilakukan dengan pendekatan kualitatif, dilandasi teori estetika dan perubahan sosial. Hasil penelitian ini yaitu proses perwujudan kerajinan patung kayu mulai dari eksplorasi ide, bentuk, pemilihan material, alat, proses kerja dan finishing. Produk yang dihasilkan berupa patung Garuda Wisnu, Rama Shinta, Hanoman, Naga Cina, Kwan Im, Toa Pe Kong, Budha, Barong, Rangda, Saraswati, Sri, Durga, Dewa Siwa, Ganesa dan patung Kwan Sing Tee Koen. Pasang surut kerajinan patung kayu dapat ditinjau dari tahun 1970. Pada tahun itu sudah ada sekitar dua puluh orang yang mahir membuat patung dan mengembangkannya, misalnya patung Garuda, Ramayana, dan lain-lain. Adanya kerajinan tersebut, memiliki peluang pemasaran dan memotivasi perajin untuk meningkatkan kreatifitasnya. Ketika terjadi bom Bali I, pasar globalisasi, dan virus corona, kerajinan tersebut mengalami penurunan, namun perajin tetap memproduksi kerajinan tersebut.
\end{abstract}

\section{Pendahuluan}

Gianyar merupakan salah satu kabupaten di propinsi Bali yang mendapat julukan sebagai "Bumi Seni". Predikat Bumi Seni yang disandang kabupaten Gianyar tidak lepas dari banyaknya karya seni yang bersifat monumental lahir di kabupaten tersebut. Serta semakin berkembangnya berbagai bentuk maupun jenis karya seni misalnya: seni tari, tabuh, seni rupa dan lain-lain. Di Kabupaten Gianyar ada salah satu desa yang melahirkan kerajinan patung kayu yaitu Desa Batubulan Kangin.

Desa Batubulan kangin lahir pada tanggal 12 juli 1986 yang merupakan hasil pemekaran Desa Batubulan. Desa Batubulan Kangin terdiri dari dua desa adat, yaitu Desa Adat Batuyang dan Batuaji. Dengan terbentuknya Desa Batubulan Kangin, merupakan 
idaman masyarakatnya dan menjadi tantangan bagi pemimpin masyarakat untuk merealisir harapan akhir dari seluruh warganya untuk membentuk masyarakat yang utuh, memberikan suasana segar dan sejahtra (Anonim, 1988: 2).

Adapula mata pencaharian masyarakat Batubulan Kangin, disamping hidup sebagai petani, kini sudah banyak terjun kedunia usaha (wiraswasta), trutama dalam hal perdagangan, pariwisata, pertukangan, perkebunan dan peternakan. Perdagangan misalnya dalam bidang industri, sektor sandang, logam dan sektor kerajinan. Sektor kerajinan misalnya: anyaman bambu, payung adat, pembuatan sanggah, canang, lukisan dan kerajinan patung kayu.

Kerajinan patung kayu di Desa Batubulan Kangin di awali dari tahun 1968. Proses belajar pembuatan patung kurang lebih dari dua puluh orang, masing-masing mengambil tempat berbeda di Desa Guwang. Sekitar tahun 1970, setelah keseluruhan orang tersebut mahir membuat patung, barulah mereka mengembangkan skilnya di desa sendiri. Pertama-pertama dikembangkan patung Garuda, kemudian patung dengan cerita Ramayana, Mahabrata, patung Naga Cina dan lain-lain.

Dengan adanya kerajinan patung kayu di Desa Batubulan Kangin, memiliki peluang pemasaran yang semakin luas dan dapat memotivasi para perajin untuk meningkatkan kreatifitasnya menciptakan kerajinan patung kayu yang baru, lebih unik dan artistik. Dalam perkembangannya kerajinan patung kayu tidak saja sebagai barang souvenir bagi para wisatawan yang datang ke Bali, tetapi juga sebagai barang ekspor yang dijual di berbagai mancanegara sebagai barang dekorasi.

Ketika kerajinan patung kayu menjadi primadona yang diminati oleh masyarakat luar, masyarakat Batubulan Kangin sangat produktif. Sebagian besar masyarakat Batubulan Kangin menggeluti kerajinan patung kayu, di samping pelaku pariwisata lainnya. Kerajinan patung kayu tidak saja digeluti oleh kaum laki-laki, tetapi juga digeluti oleh kaum wanita yang terlibat dalam mengerjakan hal-hal ringan atau sebagai pengepul yang siap untuk dipasarkan (Suardana, dkk. 2014: 2).

Berkembangnya kerajinan patung kayu di Desa Batubulan Kangin tidak terlepas dari kreativitas dan inovasi para perajin dalam menciptakan disain-disain baru yang disesuaikan dengan selera pasar. Selain itu banyak disain-disain baru yang dibawa langsung oleh konsumen dari luar dan dikerjakan oleh perajin Batubulan Kangin. Tidak jarang disain yang datang dari luar dikombinasi dengan disain lokal sehingga menghasilkan disain baru yang lebih unik dan menarik. 
Ketika terjadi bom Bali I di Kuta pada tgl 12 oktober 2002, kerajinan patung kayu di Desa Batubulan Kangin mengalami penurunan seiring dengan lumpuhnya pariwisata Bali secara umum. Situasi ini sebenarnya tidak berlangsung lama karena kerajinan patung kayu tetap jalan dan eksis, tetapi volumenya sedikit berkurang.

Kerajinan patung kayu di Desa Batubulan Kangin sebagai bagian instrumen pariwisata, selalu mengalami pasang-surut perkembangan seiring pariwisata Bali. Apalagi dunia ini memasuki pasar globalisasi yang ditandai dengan canggihnya informasi dan persaingan sangat ketat. Kerajinan patung kayu di Desa tersebut mengalami penurunan. Namun aktifitas perajin dalam memproduksi kerajinan patung kayu tetap jalan akan tetapi volumenya menurun.

\section{Metode}

Metode mempunyai pengertian yaitu cara sistematis dan terpikir secara baik yang dipergunakan dalam mengumpulkan data untuk mencapai tujuan penelitian (Fajri dan Ratu Aprilia Senja, tt: 565). Dalam penelitian ini dirancang menggunakan penelitian deskritif yaitu penelitian yang bertujuan untuk mendeskrifsikan, mencatat, menganalisis dan menginterprestasi kondisi-kondisi sekarang ini yang terjadi dilapangan. Untuk memberikan gambaran dan uraian tentang objek yang diteliti, maka jenis dan pendekatan penelitian sangatlah penting dalam penyusunan karya ilmiah. Adapun jenis penelitian yang digunakan yaitu penelitian kualitatif. Penelitian kualitatif yaitu penelitian yang menghasilkan data deskripsi berupa kata-kata tertulis atau lisan dari orang-orang dan prilaku yang dapat diamati. Pendekatan diarahkan pada latar dan individu tersebut secara utuh (Moleong, 1995: 3). Dalam penelitian ini, jenis dan pendekatan kualitatif merupakan metode yang digunakan untuk melakukan peninjauan terhadap objek yang diteliti.

Salah satu fase terpenting dari sebuah penelitian adalah langkah pengumpulan data. Berkaitan dengan langkah pengumpulan data dan jika mengacu pada jenis maupun sumber data yang akan dicari, maka teknik pengumpulan data dalam penelitian ini dilakukan dengan cara interaktif dan non-interaktif. Pengumpulan data dengan cara interaktif dilakukan melalui teknik observasi dan wawancara mendalam. Sedangkan pengumpulan data dengan cara non-interaktif dilakukan melalui teknik studi dokumen yang ada kaitannya dengan penelitian ini.

Selanjutnya analisis data, dalam konteks penelitian ini dapat dijelaskan, yakni sebuah proses pengurutan data dan menyusunanya ke dalam suatu pola, katagori dan 
satuan uraian dasar tertentu. Dengan mengacu pada batasan tersebut dan jika dikaitkan dengan penelitian ini, maka teknik analisis data yang digunakan adalah teknik analisis kualitatif. Analisis kualitiatif adalah teknik analisis yang dilakukan dari sejak awal, bersamaan dengan proses pengumpulan data. Artinya, saat melakukan analisis peneliti menyusun temuan dalam bentuk konsep, katagori atau hipotesis dan sekaligus memverifikasinya lewat pengumpulan dan analisis data, sehingga memungkinkan menghasilkan suatu teori grounded, yakni teori yang membumi karena dibangun berdasarkan data kancah. Proses analisis data dalam penelitian ini, dilakukan mulai saat pengumpulan data berlangsung dan setelah selesai pengumpulan data dalam periode tertentu. Pada saat wawancara dilakukan, peneliti sebenarnya sudah melakukan analisis terhadap jawaban-jawaban yang diberikan oleh informan. Kemudian jika jawabanjawaban yang diberikan oleh informan setelah dianalisis dirasa belum memuaskan, maka peneliti akan menggali lagi data melalui pertanyaan-pertanyaan secara lebih mendalam kepada para informan, sampai data yang diproleh dianggap kredibel.

Menurut Miles dan Huberman (dalam Sugiono, 2011: 337) aktivitas yang dilakukan dalam proses analisis data adalah dengan cara interkatif dan berlangsung secara terus menerus sampai tuntas dan sampai datanya jenuh. Tahapan-tahapan analisis data interaktif menurut Miles dan Huberman adalah data reduction, data display dan conclusion drawing/verification. Maksudnya penyajian data, reduksi data dan penarikan simpulan atau verifikasi merupakan rangkaian kegiatan yang tidak terpisahkan satu sama laiannya. Dalam penelitian ini kegiatan pengumpulan data merupakan proses siklus yang bersifat interaktif, yakni bergerak bolak-balik di antara kegiatan reduksi, penyajian dan penarikan simpulan selama sisa waktu penelitian.

\section{Hasil dan Pembahasan}

\section{Proses Perwujudan Kerajinan Patung Kayu Pada Industri Pariwisata Di Desa Batubulan Kangin}

Proses perwujudan kerajinan patung kayu di Desa Batubulan Kangin, di awali dengan eksplorasi. Dalam tahapan eksplorasi ini ada dua langkah yang dilakukan perajin yaitu eksplorasi internal dan eksternal. Eksplorasi internal itu menyangkut tentang ide, pengalaman, pemahaman dan yang lainnya. Sedangkan eksplorasi eksternal itu menyangkut tentang bentuk patung dan material yang digunakan (Gustami, 2007: 329). 
Selain itu adapula alat, teknik, proses kerja dan finishing yang diterapkan oleh perajin patung kayu di Desa Batubulan Kangin.

\section{a. Eksplorasi Ide}

Eksplorasi ide yang dilakukan para perajin patung kayu di Desa Batubulan Kangin, tidak terlepas dari adanya pengalaman belajar di Desa Guang, diawali membuat patung Kadal dan patung Garuda. Tidak hanya itu untuk mengembangkan kerajinannya para perajin patung kayu juga mendengarkan kisah cerita Ramayana, mahabarat, melihat patung yang ada di Desa Ubud, melihat gambar patung yang ada di buku, majalah, televisi dan lain sebagainya. Dengan adanya cerita maupun gambar-gambar tersebut maka perajin patung kayu di Desa Batubulan Kangin mendapatkan ide untuk membuat kerajinan patung kayu. Dengan cara melihat secara teliti, merasakan dan merekamnya dalam benak para perajin, kemudian dituangkan dalam media kayu sesuai dengan ide. Melalui tangan terampil maka terwujudlah kerajinan patung kayu sesuai dengan ide para perajin dengan bentuk beraneka ragam misalnya: patung Garuda Wisnu, Rama Sita, Dewi Kwan Im, Naga Cina dan lain sebagainya.

\section{b. Eksplorasi Bentuk}

Bentuk kerajinan patung kayu di Desa Batubulan Kangin merupakan variasi bentuk manusia, pewayangan dan bentuk hewan, dihiasi dengan motif ornamen taradisonal Bali. Dengan menggunakan material utama berupa kayu, yang terdiri dari: kayu cendana, panggal buaya, gaharu, waru dan kayu munggur (suar). Terpenting dalam pemilihan material kayu dapat menunjang kekuatan fisik patung, tahan terhadap serangan hama, memilik karakter, serat unik dan memiliki warna kayu yang menarik. Selain itu adapula teknik yang digunakan yaitu teknik ukir dan terakhir difinishing menggunakan amplas kemudian dipoleskan semir secara transparan dengan tujuan untuk memperlihatkan serat kayunya. Kesemuanya itu dikemas dan diolah sedemikian rupa sehingga terbentuklah kerajinan patung kayu sesuai dengan keinginan perajin. Kerajinan patung kayu ini berbentuk tiga dimensional yang dapat dilihat dari segala arah, baik itu tampak depan, samping dan atas. Untuk mencapai kesatuan dari sebuah kerajinan patung kayu, perajin tetap melakukan beberapa hal yaitu: pertama, berdasarkan pada unsur-unsur seni rupa baik itu garis, bentuk, warna, ruang, tekstur, komposisi, proporsi, irama dan kesatuan. Kedua memberikan bobot seni misalnya kerumitan, kesederhanaan dan pusat perhatian. 


\section{c. Pemilihan Material}

Dalam membuat kerajinan patung kayu adapun material yang digunakan yaitu: kayu cendana, gaharu, panggal buaya, waru dan kayu munggur (suar). Kesemuanya memiliki kelas keawetan, serat dan warna yang berbeda. Hal terpenting dalam pemilihan material kayu adalah dapat menunjang kekuatan fisik, keutuhan bentuk, memiliki karakter, tahan terhadap serangan hama dan memiliki nilai estetik. Untuk mendapatkan hal tersebut kayu harus benar-benar kering, memiliki warna, serat untuk menunjang patung, mudah dikerjakan, kayu tidak menimbulkan alergi dan mudah difinishing. Selain itu adapula bahan bantu terdiri dari lem, yaitu lem poxs dan lem $G$ dari jenis cyanoacrilate. Kedua lem ini digunakan untuk menempel bagian-bagian dari kerajinan patung kayu apabila ada yang pecah dan lain sebagainya. Tidak hanya itu adapula bahan finishing yang digunakan yaitu amplas dan semir.

\section{d. Persiapan Alat}

Alat utama yang digunakan dalam pembuatan kerajinan patung kayu yaitu seprangkat pahat ukir terdiri dari pahat pemuku, perancab, penyengkrong, penatar, penyisir serta digunakan pula pangot dan mutik. Pemukulnya (pengotok) terbuat dari bahan kayu yang diambil dari kayu asem (celagi). Selain itu adapula alat pertukangan dipergunakan misalnya gergaji tangan, mesin bor merek bosch tipe GSB $16550 \mathrm{~W}$, grinda merek bosch tipe GWS 6-100 dan mesin sensor merek stihl tipe MS 260.

\section{e. Proses Kerja}

Dalam perwujudan kerajinan patung kayu adapun proses kerja yang dilalui perajin patung kayu di Desa Batubulan Kangin yaitu: (1) pembentukan secara global, dengan menggunakan mesin sensor, apabila bahan kayu masih berbentuk glondongan atau langsung membentuk menggunakan pahat apabila kayunya kecil. Di dalam pembentukan global ini diperlukan daya-daya pemikiran yang matang agar sesuai dengan ide awal. Proses pembentukan awal, perajin harus memahami bentuk yang matang baik yang akan ditonjolkan maupun bagian-bagian tenggelam. Apabila tidak memahami bentuk bisa jadi wujud patung meleset dari ide awal. (2) Pembuatan detail dan menghaluskan. Tahap ini menggunakan pahat, yang disesuaikan dengan bentuk detailnya. Baik penegasan garis, bidang datar, ruang, bentuk cekung, maupun cembung, tembus serta tekstur. Tahap ini sangat diperlukan keihlaian permainan pahat, karena dengan adanya permainan pahat yang nampak dalam patung, itu mencerminkan khas pribadi perajinnya. (3) Membuat hiasan, bagus dan tidaknya suatu patung, juga ditentukan oleh hiasan patung itu sendiri. 
Karena dalam menghias patung juga diperlukan ketrampilan membuat sketsa dan mengukir. Mengukir diperlukan ketelatenan dan keihlaian permainan pahat yang tinggi. Dengan ketelatenan dan keihlaian yang tinggi dimiliki oleh perajin patung kayu, akan menghasilkan hiasan ukiran yang menarik dilihat. (4) Membuat muka atau (ngemuin). Tahap ini di dalam kerajinan patung kayu sangat penting, karena membuat muka sesuai dengan karakter patung yang diinginkan sangatlah sulit. Sehingga diperlukan ketelatenan dan permainan pahat yang tinggi dalam pembuatan muka. Dengan keahlian yang tinggi dimiliki oleh perajin patung kayu di Desa Batubulan Kangin akan menghasilkan muka patung sesuai dengan kenyataannya.

\section{f. Finishing}

Finishing merupakan proses akhir dalam pembuatan kerajinan patung kayu. Keberhasilan sebuah patung juga ditentukan oleh finishing yang sempurna. Pengamplasan merupakan bagian dari tahap finishing yang tujuannya yaitu membersihkan pahatan-pahatan, menghaluskan patung dan memperjelas serat kayu. Proses akhir adalah pelapisan menggunakan semir dan digosok dengan sikat halus setelah kering. Penyemiran tujuannya yaitu memperkilap kerajinan patung kayu dan kesan semir seolah-olah menyatu dengan kayu. Kerajinan patung kayu di Desa Batubulan Kangin tidak semuanya di finishing ada juga yang masih utuh tujuannya untuk memperlihatkan pahatan-pahatan maupun serat alami kayunya.

\section{Produk Yang Dihasilkan Pada Kerajinan Patung Kayu Industri Pariwisata Di Desa Batubulan Kangin.}

Produk yang dihasilkan pada kerajinan patung kayu industri pariwisata di Desa Batubulan Kangin adalah bentuk patung beraneka ragam. Dengan dihiasi ornamen tradisional Bali yang dimunculkan dalam bentuk ukiran. Semuanya itu dibuat oleh perajin patung kayu di desa tersebut untuk memenuhi kebutuhan wisatawan yang datang ke Bali sebagai barang sopenir. Kemampuan para perajin dalam mengolah material kayu, mengembangkan bentuk patung menyebabkan produk kerajinan patung kayu sangat bervariatif namun tetap kental dengan gaya Balinya. Adapun produk kerajinan patung kayu tersebut adalah sebagai berikut. 


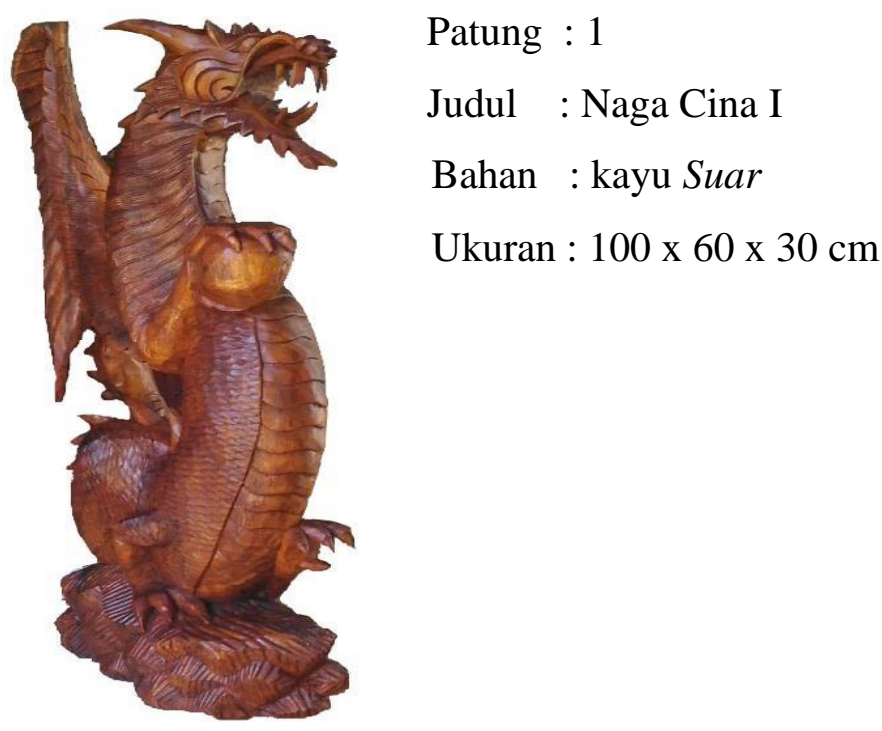

\section{a. Deskripsi Patung Pertama}

Kerajinan patung ini berjudul Naga Cina I. Menampilkan satu bentuk patung naga cina dengan memperlihatkan muka yang seram, mata tajam, giginya runcing, bertanduk, badannya bersisik, memiliki sayap, kakinya empat dengan telapak kaki menyerupai harimau dan patung ini berdiri di atas bebatuan.

Patung ini juga menampilkan garis lurus, lengkung dan bergelombang yang menimbulkan kesan irama sehingga patung kelihatan dinamis dan harmoni. Patung ini difinishing dengan menggunakan semir coklat dipoleskan secara transparan, bertujuan untuk memperlihatkan serat kayunya. Dengan bentuk tiga dimensional yang dapat dilihat dari segala arah baik itu tampak depan, samping dan atas. Adapun teknik yang digunakan dalam kerajinan patung ini yaitu teknik ukir. Dengan menggunakan material utama yaitu kayu suar.

Kerajinan patung ini merupakan refresentasi dari gambar atau patung Naga Cina. Naga Cina adalah makhluk legenda dalam mitos dan budaya rakyat Cina. Naga Cina sesungguhnya memiliki 9 karakteristik yang merupakan kombinasi dari makhlukmakhluk lainnya. Adapun 9 karakteristik tersebut antara lain: memilik kepala seperti unta, sisiknya menyerupai ikan, tanduknya seperti rusa, matanya seperti kelinci, telinganya seperti sapi, lehernya seperti ular, perutnya seperti kerang, telapak kakinya seperti macan dan cakarnya seperti elang. Naga cina merupakan suatu simbol dari kekuatan yang dapat memberikan kebaikan dan keberuntungan bagi umat manusia (Yoswara, dkk. 2011, journal.itb.ac.id., di akses tanggal 26 Agustus 2020). 


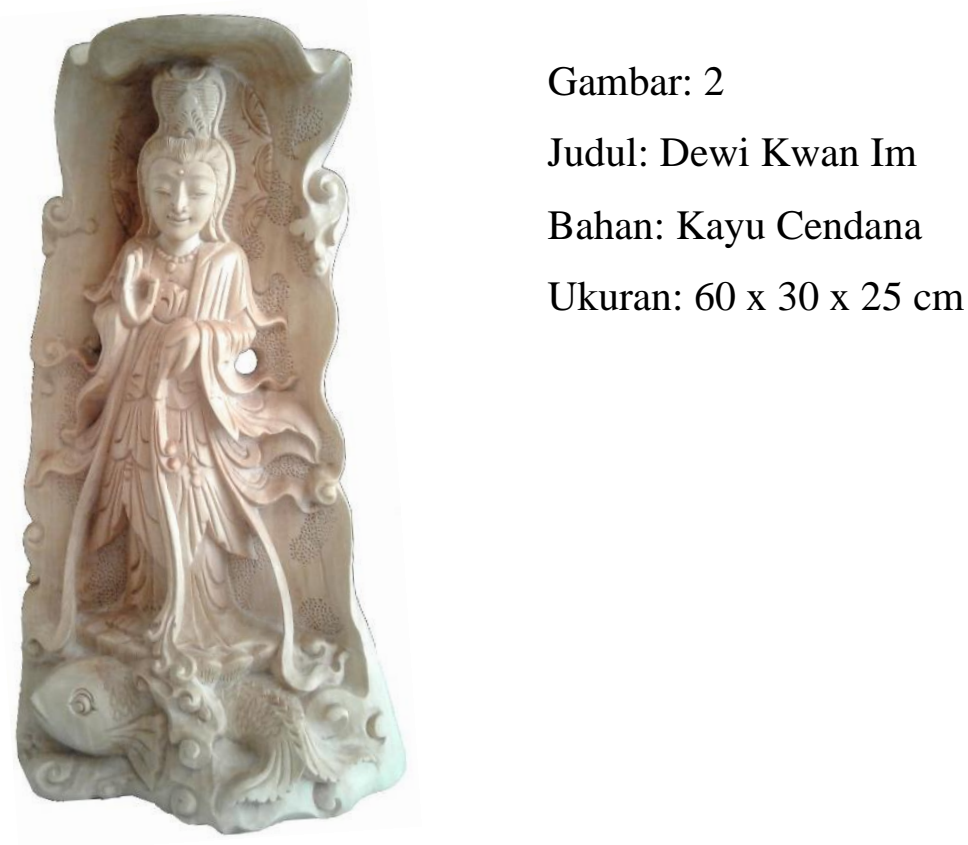

\section{b. Deskripsi Patung Kedua}

Kerajinan patung ini berjudul, Dewi Kwan Im. Patung ini memperlihatkan wujud perempuan, dengan wajah cantik keibuan penuh keagungan, memakai gaun mengikuti lekukan tubuhnya yang indah, tangan kiri memegang botol, sedangkan tangan kanan ibu jarinya bersentuhan dengan jari tengah menghadap ke samping kiri. Patung Dewi Kwan Im ini berdiri di atas bunga teratai dan di bawahnya terdapat satu bentuk ikan. Di belakang patung Dewi Kwan Im ini dari bawah sampai atas memperlihatkan bentuk batu-batuan yang di isi tekstur dan lekukan-lekukan menyesuaikan dengan patungnya.

Kerajinan patung ini menampilkan beberapa garis diantaranya garis lurus, lengkung dan bergelombang yang menimbulkan kesan irama sehingga patung kelihatan dinamis dan harmoni. Patung ini tanpa difinishing hanya memperlihatkan warna alami kayunya semata. Dengan bentuk tiga dimensional yang dapat dilihat dari segala arah baik itu tampak depan, samping dan atas. Patung ini menggunakan teknik ukir, dengan menggunakan material utama yaitu kayu cendana.

Kerajinan patung ini terinspirasi dari gambar atau patung Dewi Kwan Im di Cina. Dewi Kwan Im atau Dewi Guan Yin adalah Dewi Welas Asih dan penyayang yang popular di puja masyarakat Tiongkok dan perantauannya di dunia. Sebutan Kwan Im sendiri berasal dari dialek Hokkian yang umum dipergunakan mayoritas etnis Tionghoa di Indonesia. Secara harfiah, Guan artinya melihat dan Yin artinya suara (mendengar). Jadi asal melihat atau mendengar ada yang minta tolong (khususnya perempuan) Dewi Kwan Im akan datang dan turun menolong. Perwujudan Dewi Kwan Im ini dapat 
dipisualisasikan sebagai seorang perempuan yang umurnya masih muda sekitar 30-an dan di dahinya tidak terdapat titik merahnya. Perwujudan Kwan Im sebagai sosok wanita lebih jelas pada masa Dinasti Yuan (1206-1368). Sejak masa dinasti Ming (1368-1644) atau sekitar abad 15, Dewi Kwan Im secara menyeluruh perwujudannya dikenal sebagai seorang wanita. Untuk memperingati atau menghormati Dewi Kwan Im ini ada 3 hari besar dan suci yaitu: (1) tanggal 19 bulan 2 Imlek adalah hari kelahirannya. (2) Tanggal 19 bulan 6 Imlek adalah hari mencapai kesempurnaan. (3) Tanggal 19 bulan 9 Imlek adalah hari meninggalkan raganya. Pada hari ini umat yang merasa pernah memperoleh pertolongan Dewi Kwan Im umumnya akan datang memenuhi klenteng, membawa barang persembahan, melepaskan burung atau hewan lainnya, melakukan pantangan dan melaksanakan perbuatan amal (Tan, 2016, http://www.tionghoa.info., diakses tanggal 10 Juni 2020).

Selain itu adapula 20 ajaran welas asih Dewi Kwan Im yang patut diikuti oleh umatnya yaitu: (1) Jika orang lain membuatmu susah, anggaplah itu tumpukan rejeki. (2) Mulai hari ini belajar menyenangkan hati orang lain. (3) Jika kamu merasa pahit dalam hidupmu dengan suatu tujuan itulah bahagia. (4) Lari dan berlarilah untuk mengejar hari esok. (5) Setiap hari kamu harus merasa puas dengan apa yang kamu miliki saat ini. (6) Setiapkali ada orang memberimu satu kebaikan, kamu harus mengembalikannya sepuluh kali lipat. (7) Nilailah kebaikan orang lain kepadamu, tetapi hapuskanlah jasa yang pernah kamu berikan pada orang lain. (8) Dalam keadaan benar difitnah dipersalahkan dan dihukum maka kamu akan mendapatkan pahala. (9) Dalam keadaan salah kamu dipuji dan dibenarkan itu merupakan hukuman. (10) Orang yang benar kita bela, tetapi yang salah kita beri nasihat. (11) Jika perbuatan kamu benar, kamu difitnah dan dipersalahkan, tapi kamu menerimanya maka akan datang kepadamu rejeki yang berlimpah ruah. (12) Jangan selalu melihat atau mengecam kesalahan orang lain, tetapi selalu melihat diri sendiri itulah kebenaran. (13) Orang yang baik diajak bergaul, yang jahat dikasihani. (14) Kalau wajahmu senyum hatimu senang, pasti kamu akan aku terima. (15) Dua orang saling mengakui kesalahan masing-masing, maka dua orang itu akan bersahabat sepanjang masa. (16) Saling salah menyalahkan maka akan mengakibatkan putus hubungan. (17) Kalau kamu rela dan terus menolong orang kesusahan maka jangan sampai kamu diketahui sebagai penolongnya. (18) Jangan membicarakan sedikitpun kejelekan orang lain dibelakangnya, sebab kamu akan dinilai jelek oleh si pendengar. (19) Kalau kamu mengetahui seseorang berbuat salah, maka tergurlah langsung dengan kata- 
kata yang lemah lembut hingga orang itu insaf. (20) Doa dan sembah sujudmu akan aku terima, apabila kamu bisa sabar dan menuruti jalanku (Tan, 2016, http://www.tionghoa.info., diakses tanggal 10 Juni 2020). Jadi dari apa yang telah dijelaskan sebelumnya maka Dewi Kwan Im merupakan lambang kewelas-asihan dan penyayang terhadap manusia yang ada di dunia ini.

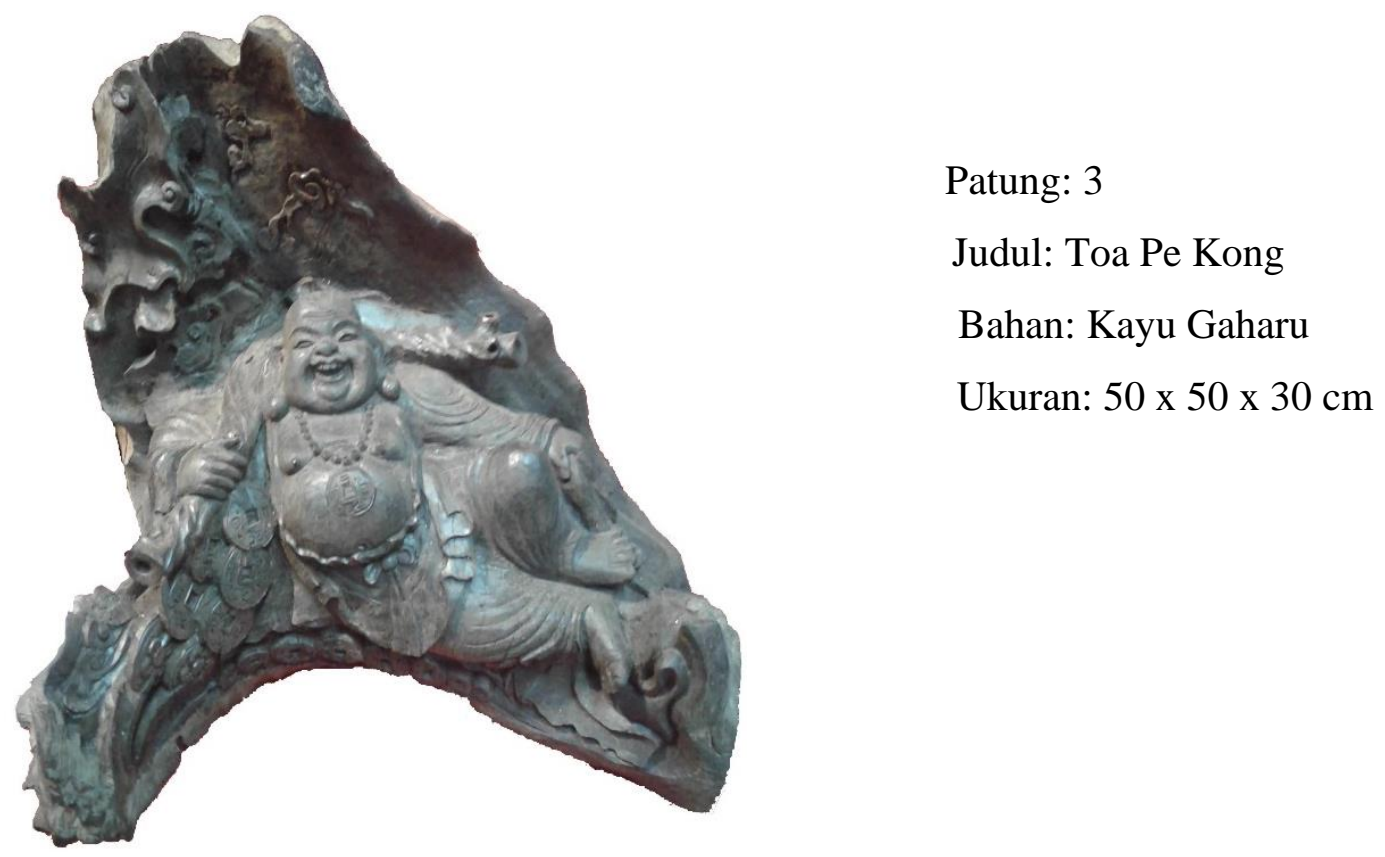

\section{c. Deskripsi Patung Ketiga}

Kerajinan patung ini berjudul Toa Pe Kong. Dengan menampilkan bentuk patung laki-laki, duduk sambil bersandar pada uang kepeng. Patung ini menampilkan wajah yang lucu, kepala botak, telinga panjang, memperlihatkan susu dan perut besar. Dengan tangan kanan memegang kayu diletakkan di atas bahu dan tangan kiri terlentang memegang karung. Di belakang patung memperlihatkan bentuk batu-batuan yang disesuaikan dengan wujud patungnya. Patung Toa Pe Kong ini memakai jubah mengikuti lekukanlekukan bentuk badannya.

Patung ini juga memperlihatkan beberapa garis misalnya garis lurus, lengkung dan bergelombang yang menimbulkan kesan irama sehingga patung kelihatan dinamis dan harmoni. Patung ini tanpa difinishing hanya memperlihatkan warna alami kayunya semata. Dengan bentuk tiga dimensi yang dapat dilihat dari segala arah baik itu tampak depan, samping dan atas. Adapun teknik yang digunakan dalam kerajinan patung ini yaitu teknik ukir. Dengan menggunakan material utama yaitu kayu gaharu.

Kerajinan patung ini merupakan refresentasi dari gambar atau patung Toa Pe Kong di Cina. Toa Pe Kong adalah patung dewa yang dianggap sebagai penyelamat bagi 
umat Khonghucu atau sebagai dewa bumi dan kekayaan. Patung Toa Pe Kong di Negara Cina biasanya disembah oleh umatnya untuk memohon keselamatan dan kemurahan rejeki.

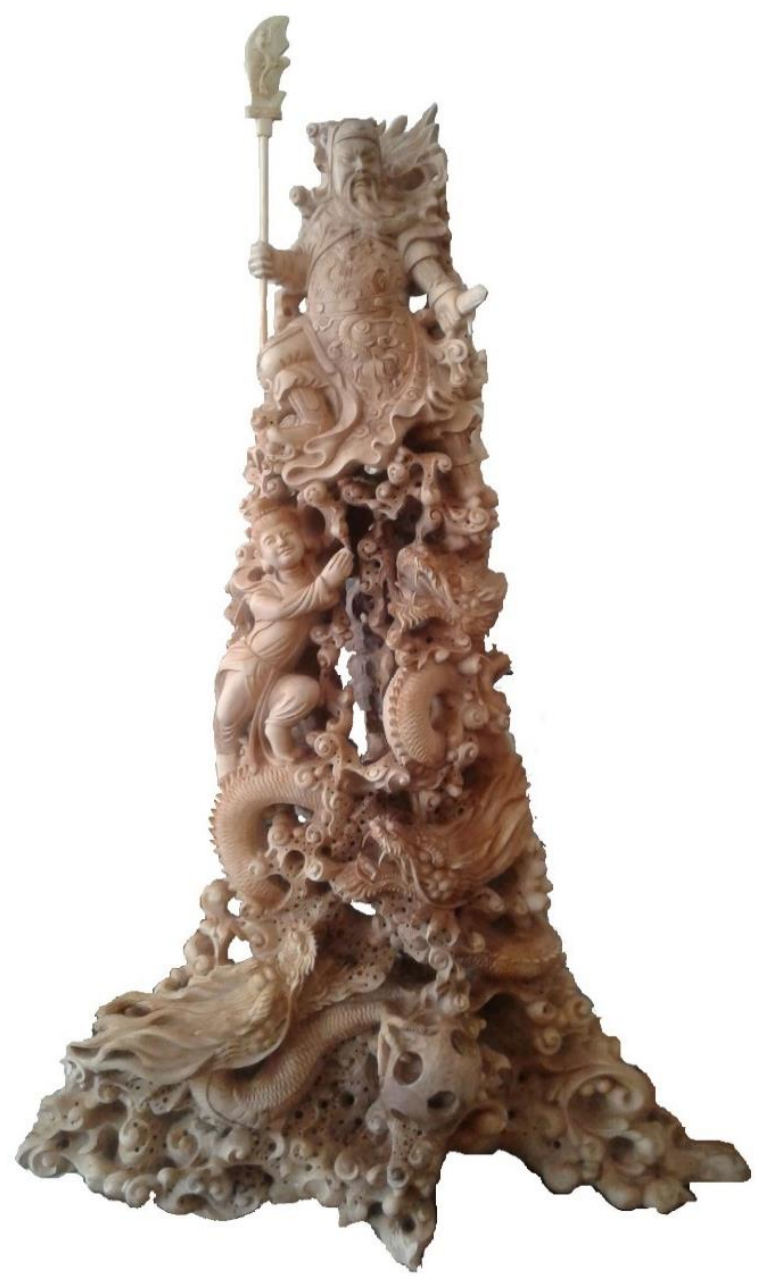

Gambar: 4

Judul: Dewa Kwan Sing Tee Koen, Manusia dan Naga Cina

Bahan: Kayu Cendana

Ukuran: $100 \times 60 \times 50 \mathrm{~cm}$

\section{d. Deskripsi Patung Keempat}

Kerajinan patung ini berjudul, Dewa Kwan Sing Tee Koen, Manusia dan Naga Cina. Patung Dewa Kwan Sing Tee Koen letaknya paling atas dibandingkan dengan patung yang lainnya. Patung Dewa Kwan Sing Tee Koen menampilkan bentuk patung laki-laki, berkepala dengan rambut panjang, memiliki jenggot, berbadan kekar, memakai jubah berhiaskan naga, tangan kanan memegang senjata menyerupai pedang, tangan kiri memegang pisau kecil, kakinya memakai sepatu dan menginjak bebatuan. Di bawah patung Dewa Kwan Sing Tee Koen ini, terdapat bentuk manusia laki-laki berdiri di atas patung Naga, memakai jubah mengikuti lekukan tubuhnya yang sedang mencakupkan tangannya. Di sebelah kiri dan di bawah patung manusia, terdapat tiga bentuk patung Naga Cina. Dengan memperlihatkan muka yang seram, mata tajam, giginya runcing, 
bertanduk, badannya bersisik, kakinya empat dengan telapak kaki menyerupai harimau dan patung ini melilit di sela-sela bebatuan.

Patung ini juga menampilkan garis lurus, lengkung dan bergelombang yang menimbulkan kesan irama sehingga patung kelihatan dinamis dan harmoni. Patung ini tanpa difinishing hanya memperlihatkan warna alami kayunya semata. Dengan bentuk tiga dimensional yang dapat dilihat dari segala arah baik itu tampak depan, samping dan atas. Adapun teknik yang digunakan dalam kerajinan patung ini yaitu teknik ukir. Dengan menggunakan material utama yaitu kayu cendana.

Kerajinan patung ini merupakan refresentasi dari patung Dewa Kwan Sing Tee Koen, manusia dan Naga Cina. Dewa Kwan Sing Tee Koen di anggap sebagai simbol kesetiaan dan kejujuran. Dewa Kwan Sing Tee Koen adalah lambang teladan sifat kesatria yang selalu menempati janji dan setia pada sumpahnya. Selain dipuja sebagai lambang kesetiaan dan kejujuran. Dewa Kwan Sing Tee Koen juga sebagai pelindung perdagangan, kesusastraan dan pelindung rakyat dari peperangan. Julukan Dewa Perang sebagai umumnya dikenal dan diartikan sebagai dewa untuk menghindari peperangan.

Sedangkan patung manusia laki-laki dengan tangan dicakup menjadi satu, merupakan sikap sembah (Om Swastyastu) yang dilakukan pada patung Dewa Kwan Sing Tee Koen. Om Swastyastu merupakan salam pembuka yang biasa diucapkan oleh orang Bali kepada seseorang yang ditemuinya. Om (Ong) artinya Tuhan, Su' artinya baik, Asti' artinya semoga. Salam tersebut memiliki makna mendoakan lawan bicara agar senantiasa selalu diberikan keselamatan dan kebahagian oleh sang pencipta di dalam hidupnya.

Terakhir patung Naga Cina yaitu makhluk legenda dalam mitos dan budaya rakyat Cina. Naga Cina sesungguhnya memiliki 9 karakteristik yang merupakan kombinasi dari makhluk-makhluk lainnya. Adapun 9 karakteristik tersebut antara lain: memilik kepala seperti unta, sisiknya menyerupai ikan, tanduknya seperti rusa, matanya seperti kelinci, telinganya seperti sapi, lehernya seperti ular, perutnya seperti kerang, telapak kakinya seperti macan dan cakarnya seperti elang. Naga cina merupakan suatu simbol dari kekuatan yang dapat memberikan kebaikan dan keberuntungan bagi umat manusia (Yoswara, dkk. 2011, journal.itb.ac.id., di akses tanggal 26 Agustus 2020). Adanya ketiga patung ini dengan bentuk berbeda, posisi berbeda, akan tetapi tetap menjadi satu kesatuan yang indah dan menarik untuk dipandang. 


\section{Pasang Surut Kerajinan Patung Kayu Pada Industri Pariwisata Di Desa Batubulan Kangin}

Pasang surut kerajinan patung kayu di Desa Batubulan Kangin, dapat ditinjau dari tahun 1970. Pada tahun itu di Desa Batubulan Kangin sudah ada sekitar dua puluh orang yang mampu dan mahir membuat patung kayu serta mengajar maupun mengembangkan kerajinan patung kayu. Untuk pertama kali dikembangkan patung Garuda, kemudian patung dengan cerita Ramayana dan Mahabarata. Pada tahun 1980 sampai 1988, perajin patung kayu di Desa Batubulan Kangin mampu menciptakan patung Naga Cina. Tahun 1988 sampai sekarang perajin patung kayu di desa tersebut mampu menciptakan patung beraneka ragam misalnya: patung Dewi Kwan Im, Toa Pe Kong, Buddha, Barong, Rangda, Dewi Saraswati, Sri, Dewi Durga, Dewa Siwa, Ganesa dan patung Dewa Kwan Sing Tee Koen.

Dengan adanya kerajinan patung kayu di Desa Batubulan Kangin, memiliki peluang pemasaran yang semakin luas dan dapat memotivasi para perajin untuk meningkatkan kreatifitasnya menciptakan kerajinan patung kayu yang baru, lebih unik dan artistik. Para perajin seakan berlomba-lomba untuk menciptakan sesuatu yang baru dan belum beredar di pasaran. Mereka selalu menciptakan kerajinan patung kayu yang berbeda untuk mendapatkan peluang pasar lebih luas. Dalam perkembangannya kerajinan patung kayu tidak saja sebagai barang souvenir bagi para wisatawan yang datang ke Bali, tetapi juga sebagai barang ekspor yang dijual di berbagai mancanegara sebagai barang dekorasi. Permintaan kerajinan patung kayu mengalami peningkatan yang signifikan dengan volume sangat besar. Banyak perajin yang kewalahan untuk menerima pesanan, karena jumlahnya banyak dan waktunya pendek.

Ketika kerajinan patung kayu menjadi primadona yang diminati oleh masyarakat luar, masyarakat Batubulan Kangin sangat produktif. Sebagian besar masyarakat Batubulan Kangin menggeluti kerajinan patung kayu, di samping pelaku pariwisata lainnya. Kerajinan patung kayu tidak saja digeluti oleh kaum laki-laki, tetapi juga digeluti oleh kaum wanita yang terlibat dalam mengerjakan hal-hal ringan atau sebagai pengepul untuk dipasarkan (Suardana, dkk. 2014: 2).

Peluang kerja yang terbuka, menyebabkan banyak penduduk luar berdatangan ke Batubulan Kangin untuk mendapatkan pekerjaan seperti: Buleleng, Karangasem dan Nusa Penida. Batubulan Kangin diserbu oleh tenaga-tenaga muda yang produktif dan tersebar luas di beberapa wilayah. Para pengusaha kerajinan patung kayu sangat terbantu 
dengan adanya tenaga dari luar, walaupun harus dididik dari awal karena berkaitan dengan kerajinan patung kayu yang memerlukan ketrampilan khusus.

Ketika terjadi krisis moneter pada tahun 1997-1998 yang dialami Indonesia dan Bali pada khususnya, keadan Indonesia saat itu sangat kacau banyak orang yang tidak bersalah menjadi korban luka-luka, menipisnya bahan pokok, biaya hidup semakin tinggi dan lain-lain. Namun pada saat krisis moneter, kerajinan patung kayu yang ada di Desa Batubulan Kangin melonjak naik dan banyak pesanan berdatangan sampai menumpuk, itu dikarenakan waktunya pendek. Para perajin merasa bersyukur dan bergembira pada waktu itu karena, kerajinan patung kayu tetap jalan, semakin meningkat serta berkembang.

Berkembangnya kerajinan patung kayu di Desa Batubulan Kangin tidak terlepas dari kreativitas dan inovasi para perajin dalam menciptakan disain-disain baru yang disesuaikan dengan selera pasar. Selain itu banyak disain baru yang dibawa langsung oleh konsumen dari luar dan dikerjakan oleh perajin Batubulan Kangin. Tidak jarang disain yang datang dari luar dikombinasi dengan disain lokal sehingga menghasilkan disain baru yang unik dan menarik.

Ketika terjadi bom Bali I di Kuta pada tgl 12 oktober 2002, kerajinan patung kayu di Desa Batubulan Kangin mengalami penurunan seiring dengan lumpuhnya pariwisata Bali secara umum. Situasi ini sebenarnya tidak berlangsung lama karena kerajinan patung kayu tetap jalan dan eksis, tetapi volumenya sedikit berkurang.

Kerajinan patung kayu di Desa Batubulan Kangin sebagai bagian instrumen pariwisata, selalu mengalami pasang surut perkembangan seiring dengan dinamika pariwisata Bali. Apalagi dunia ini memasuki pasar globalisasi yang ditandai dengan canggihnya informasi dan persaingan sangat ketat. Kerajinan patung kayu di Desa Batubulan Kangin mengalami penurunan. Namun aktifitas para perajin dalam memproduksi kerajinan patung kayu tetap jalan akan tetapi volumenya menurun.

Begitupula saat adanya virus corona (covid-19) tahun 2020 yang melanda dunia termasuk Indonesia dan Bali pada khususnya. Pemerintah Indonesia pada waktu itu mengimbau kepada seluruh masyarakatnya untuk berdiam diri di dalam rumah, menjaga kebersihan diri dan menggunakan masker bila keluar rumah. Hotel-hotel, restaurant, supermarket, pasar, dibatasi dalam berjualan. Tujuannya tiada lain adalah untuk memutus penyebaran virus corona yang ada di Indonesia. Pada waktu itu masyarakat Indonesia termasuk Bali merasakan adanya penurunan dalam bidang perdagangan, pariwisata, 
kerajinan patung kayu dan yang lainnya. Kerajinan patung kayu yang ada di Desa Batubulan Kangin hanya mengandalkan pariwisata, juga mengalami penurunan. Sekalipun demikian para perajin tetap memproduksi kerajinan patung kayu, namun volumenya berkurang dari sebelumnya.

\section{Kesimpulan}

Proses perwujudan kerajinan patung kayu pada industri pariwisata di Desa Batubulan Kangin dimulai dari eksplorasi internal dan eksternal. Eksplorasi internal itu menyangkut tentang ide, pengalaman, pemahaman dan yang lainnya. Sedangkan eksplorasi eksternal itu menyangkut tentang bentuk patung dan material yang digunakan. Selain itu adapula alat, teknik, proses kerja dan finishing yang diterapkan. Dengan kesemuanya itu akan terwujud kerajinan patung kayu yang diinginkan.

Produk yang dapat dihasilkan pada kerajinan patung kayu industri pariwisata di Desa Batubulan Kangin adalah bentuk patung beraneka ragam dengan dihiasi ornamen tradisional Bali. Semuanya itu untuk memenuhi kebutuhan wisatawan yang datang ke Bali sebagai barang sopenir. Kemampuan para perajin dalam mengolah material kayu, mengembangkan bentuk patung menyebabkan produk kerajinan patung kayu bervariatif namun tetap kental dengan gaya Balinya. Adapun produk kerajinan patung kayu tersebut yaitu patung Garuda Wisnu, Rama Shinta, Hanoman, Naga Cina, Dewi Kwan Im, Toa Pe Kong, Buddha, Barong, Rangda, Dewi Saraswati, Sri, Dewi Durga, Dewa Siwa, Ganesa dan patung Kwan Sing Tee Koen.

Pasang surut kerajinan patung kayu di Desa Batubulan Kangin dapat ditinjau dari tahun 1970. Pada tahun itu di Desa Batubulan Kangin sudah ada sekitar dua puluh orang yang mahir membuat patung kayu dan telah mengajar maupun mengembangkan kerajinannya. Untuk pertama kali dikembangkan patung Garuda, Ramayana, Mahabrata dan lain-lain. Adanya kerajinan tersebut, memiliki peluang pemasaran semakin luas dan memotivasi para perajin untuk meningkatkan kreatifitasnya. Ketika terjadi bom Bali I, pasar globalisasi, dan adanya virus corona tahun 2020, kerajinan patung kayu di Desa Batubulan Kangin mengalami penurunan. Sekalipun demikian para perajin tetap memproduksi kerajinan tersebut, namun volumenya berkurang dari sebelumnya. 


\section{Daftar Pustaka}

Anonim. (1988), Monografi Desa Batubulan Kangin, Gianyar: LKMD Desa Batubulan Kangin.

Fajri, Em Zul dan Ratu Aprilia Senja. (tt), Kamus Lengkap Bahasa Indonesia, Jakarta: Difa Publisher.

Gustami SP. (2007), Butir-Butir Mutiara Estetika, Yogyakarta: Prasista.

Moleong, Lexy J. (1995), Metode Penelitian Kualitatif, Yogyakarta: Rake Sarasin.

Sugiono, (2011), Metode Penelitian Pendidikan Pendekatan Kuantitatif, Kualitatif, dan $R \& D$, Bandung: Alfabeta.

Suardana, I Wayan. dkk. (2014), Terpuruknya Seni Kerajinan Di Gianyar Bali Dalam Pasar Global: Laporan Penelitian Fundamental Institut Seni Indonesia Denpasar.

Tan Herman, 2016, Ajaran Welas Asih Dewi Kwan Im. http://www.tionghoa.info., diakses tanggal 10 Juni 2020.

Yoswara, Harry Pujianta. dkk, (2011), Simbol Dan Makna Bentuk Naga Studi Kasus: Vihara Satya Budhi Bandung, journal.itb.ac.id., di akses tanggal 26 Agustus 2020. 